\title{
PENGARUH TINGKAT PENDIDIKAN, PENDAPATAN, GENDER, DAN TEMPAT TINGGAL TERHADAP AKUNTANSI RUMAH TANGGA
}

\author{
Ahmad Rudi Yulianto, Bekti Syahputra \\ Prodi Akuntansi Universitas Islam Sultan Agung \\ Riwayat Artikel: Dikirim April 2018 ; Diterima Maret 2018 ; Diterbitkan Maret 2018
}

\begin{abstract}
ABSTRAK
Berdasarkan data dari Kementerian Agama di tahun 2014, 1 dari 10 pernikahan di Indonesia berakhir dengan perceraian karena faktor ekonomi. Sedangkan hasil penelitian Vidisha (2016) menyimpulkan praktik akuntansi rumah tangga belum mendapat perhatian besar di kalangan ilmuwan akuntansi, Vidisha juga berpendapat masih sedikit yang mengetahui bagaimana akuntansi digunakan di rumah tangga. Atas dasar penelitian terdahulu peneliti memberi judul pengaruh tingkat pendidikan, pendapatan, gender, dan tempat tinggal terhadap akuntansi rumah tangga.

Tujuan penelitian mengeksplorasipenelitian-penelitian terdahulu yang terkait faktor-faktor yang membahas tentang akuntansi rumah tangga dan menerangkan beberapa variabel yang hampir sama, diantaranya tentang pengaruh tingkat pendidikan, tingkat pendapatan, gender, dan tempat tinggal terhadap penerapan akuntansi rumah tangga.Populasi penelitian di kampus Unissula Semarang, dengan sampel sebanyak 42 orang responden. Jenis penelitian menggunakan explanatory research, pengumpulan data menggunakan kuesioner yang diuji validitas dan reliabilitasnya. Metode analisis data menggunakan uji regresi linier berganda, berserta uji hipotesisnya yang sebelumnya diuji dengan uji asumsi klasik (normalitas, multikolinearitas dan heterokedastisitas).

Hasil pengolahan data diperoleh, tingkat pendidikan, tingkat pendapatan dan gender berpengaruh tehadap akuntansi rumah tangga, sedangkan variabel tempat tinggal tidak berpengaruh tehadap akuntansi rumah tangga.
\end{abstract}

Kata kunci : tingkat pendidikan, tingkat pendapatan, gender, tempat tinggal, akuntansi rumah tangga.

\section{Pendahuluan}

Statistik sosial dan kependudukan Jawa Tengah mengungkapakan hasil susenas (survei sosial ekonomi nasional) 2016 mengungkapkan bahwa keluarga di Jawa Tengah pengeluarannya sebesar 50,98\% dihabiskan untuk membeli keperluan non makanan sedangkan sebesar 49,11\% dihabiskan untuk membeli makanan. Cara mengatur keuangan rumah tangga dengan baik bukan hal mudah, jika salah dalam mengelola keuangan berdampak pada bertambahnya uang yang terbuang percuma. Permasalahan keuangan keluarga biasanya bukan dari penghasilan yang kurang, namun penyebab utama adalah cara penerapan akuntansi keluarga yang kurang tepat.

Berdasarkan data dari Kementerian Agama di tahun 2014, 1 dari 10 pernikahan di Indonesia berakhir dengan perceraian. Menurut data yang diulas oleh Badan Peradilan Agama Mahkamah Agung (MA) menyebutkan, dari dua ratus ribu perkara perceraian, sebanyak 67.891 kasus atau 24\%dikarena masalah ekonomi, disusul oleh masalah perselingkuhan sebanyak 20.199 kasus (7\%), serta 2.191 kasus (3\%) karena

Pengaruh Tingkat pendidikan...

Ahmad Rudi Yulianto, Bekti Syahputra

DOI 
kekerasan dalam rumah tangga (http:liveolive.com, 2014).Kasus perceraian yang diakibatkan adanya masalah ekonomi sangat berhubungan erat dengan ketepatan dalam pengelolaan akuntansi didalam rumah tangga.

\section{Menurut Manurung}

akuntansi rumah tangga memiliki arti sebagai sistem akuntansi menejerial atas perencanaan keuangan satu keluarga atau lebih dalam tempat tinggalnya.Mengutip dari Ramlugun (2016) praktik akuntansi rumah tangga belum mendapat perhatian besar di kalangan ilmuwan akuntansi, beliau juga berpendapat masih sedikit yang mengetahui bagaimana akuntansi digunakan di rumahtangga. Sementara itu, Ihsan (2010) menjelaskan tingkat atau jenjang pendidikan merupakan sebuah tahapan pendidikan berkelanjutan, yang ditetapkan berdasarkan - tingkat perkembangan peserta didik, tingkat kerumitan bahan pengajaran dan cara menyajikan bahan pengajaran. Secara rasional, orang akan mengharapkan pengelolaan akuntansi dalam keluarganya lebih baik disetiap waktu.

Kutipan dari Pahl (2000) menunjukkan bahwa pasangan miskin yang memperoleh pendapatan lebih rendah harus memantau situasi keuangan mereka lebih banyak daripada pasangan yang berkecukupan. Semakin sedikit uang yang ada, semakin kuat nilainya dan semakin sulit dan menuntut diterapkannya akuntansi secara penuh atau pencatatan, investasi, pengambilan keputusan,dan penganggaran dalam keluarga, dikarenakan tuntutan kebutuhan yang membuat seseorang tersebut sulit menerapkannya.

Sementara itu menurut Syifa (2011) sebagian besar rumah tangga di
Indonesia memang membagi peran pengaturan keuangan sehari-hari dimana pembelanjaan rutin menjadi tanggungjawab seorang perempuan.Sedangkan dalam penelitian Ramlugun (2016) adanya kesetaraan gender sehingga tidak hanya wanita yang dituntut mengelola keuangan rumah tangga, priapun dituntut sanggup mengelola dan membentuk keuangan yang stabil sehingga terwujud rumah tangga yang ideal dalam segi pengelolaan akuntansi rumah tangganya.

Lokasi tempat tinggal disinyalir menjadi faktor yang mempengaruhi sebuah sistem manejerial keuangan rumah tangga dapat diterapkan atau tidak.Tempat tinggal membentuk sifat seseorang dan polapikirnya.Seseorang yang tinggal diperkotaan sangat berbeda dengan seseorang yang tinggal di perdesaan.Seseorang yang tinggal diperkotaan telah mengenal dunia luas dan banyaknya masalah yang dihadapinya membuat orang tersebut memutar otak mengelola keuangan miliknya agar stabil.Sedangkan seseorang yang tinggal diperdesaan cenderung memanfaatkan sesuatu yang ada di sekitar mereka untuk memenuhi kebutuhannya.

Norhayati (2016) mengemukakan manejemen keuangan untuk pengeluaran dan pendapatan rumah tangga telah menjadi area penting yang belum dipetakan untuk penelitian.Penelitian sebelumnya menunjukan bahwa akuntansi rumah tangga yang dilakukan oleh individu dan keluarga bervariasi menurut jenis kelamin dan kelas. Purwidianti (2016) menjelaskan financial management behavior berhubungan dengan tanggungjawab keuangan seseorang mengenai cara pengelolaan 
rumah tangga mereka.

Menurut Manurung (2013) di Indonesia

penelitianmengenaiakuntansikeluarga

memangmasihbelum

terlaludiminati".Sedikitnya penelitian atas akuntansi rumah tangga di Indonesia,

serta data Kementrian Agama yang menyatakan bahwa perceraian terjadi dikarenakan ketidakstabilan keuangan rumah tangga, yang dipicu atas dasar kurangnya pemahaman pengelolaan akuntansi dalam rumah tangga.

\section{Telaah Literatur dan Hipotesis}

Harjanto (2014) menjelaskan bahwa teori kontinjensi muncul sebagai jawaban atas pendekatan "universalitik" bahwa desain pengendalian yang optimal dapat diterapkan dalam entitas secara keseluruhan.Pedekatan pengendalian yang universalistic adalah peluasan teori manejemen ilmiah yang alami.Kontinjensi (contingency) memiliki beberapa arti diantaranya kotinjensi menurut akuntansi adalah teori kepemimpinan sedangkan dalam akuntansi menejemen dijelaskan oleh Otley dalam Harjanto (2014)tidak ada sistem akuntansi manajemen yang dapat diterapkan secara universal. Keefektifan penerapan sebuah sistem bergantung kepada kesesuaian antara sistem tersebut dengan lingkungan dimana sistem tersebut diterapkan. Lebih lanjut, Otley menekankan bahwa desain sistem pengendalian dan perencanaan merupakan keadaan khusus yang tidak ada ketentuan umum mengenai apa yang seharusnya dilakukan dalam situasi khusus tersebut dan ada ketidakpastian atau kontinjensi (contingency) dari aktivitas dan teknik yang membangun sistem pengendalian dan sistem perencanaan suatu organisasi”.
Davis, dkk dalam Rani (2014)menyatakan teori kontijensi dapat digunakan untuk semua pengetahuan yang mutakhir tentang organisasi dengan cara yang paling tepat, karena tindakan yang tepat bergantung pada variabel situasional Asri dkk (2013)menyebutkan bahwa penelitian dalam bidang akuntansi manajemen melakukan pengujian untuk menganalisa hubungan variabel-variabel kontekstual, seperti ketidakpastian lingkungan, ketidakpastian tugas, struktur, kultur organisasional, dan ketidakpastian strategi dengan desain sistem akuntansi manajemen.Teorikontijensidalam

penelitian ini mengargumenkan bahwa tingkat pendidikan, pendapatan, gender, dan tempat tinggalseseorangberpengaruh untuk tercapainyasuatu kualitas akuntansi rumahtanggayangbaik,

bergantungpadasuatu kondisi tertentu.

Tingkat Pendidikan dan Akuntansi Rumah Tangga

Menurut Notoatmodjo (2010) pendidikan adalah upaya persuasi atau pembelajaran kepada masyarakat, agar masyarakat mau melakukan tindakantindakan (praktik) untuk memelihara (mengatasi masalah- masalah), dan meningkatkan kesehatannya.Buku ikhtisar data pendidikan tahun 2016/2017 (2017: 23) menerangkan ada sebanyak

2.205 laki-laki dan wanita di Jawa Tengah yang memilih putus sekolah sejak sekolah dasar. Menurut Karnawan(2016) pendidikan adalah segala usaha yang memiliki tujuan mengembangkan sikap, kepribadian, pengetahuan dan ketrampilan pendidikan sebagai tulang punggung kemajuan suatu negara, menentukan tinggi rendahnya derajat dan kedudukan bangsa. 
PenelitianRamlugun menjelaskan adanya hubungan antara pendidikan terhadap penerapan akuntansi rumah tangga, hal ini dikarenakan dengan tingkat pendidikan yang tinggi diharapkan untuk penerapan praktik akuntansi dalam rumah tangga seseorang yang lebih baik.Berdasarkanteoridanpenelitiansebelu mnya, maka dapat dihipotesiskan bahwa:

\section{$\mathrm{H}_{1}$ :Tingkat}

\section{PendidikanberpengaruhterhadapPener apan akuntansi rumah tangga}

\section{Tingkat Pendapatandan Akuntansi Rumah Tangga}

Menurut

Warfield

(2011)

Pendapatan adalah arus masuk bruto dari manfaat ekonomi yang timbul dari aktivitas normal entitas selama suatu periode, jika arus masuk tersebut mengakibatkan kenaikan ekuitas yang tidak berasal dari kontribusi penanaman modal. Tingkat pendapatan termasuk penyebab diterapkannya akuntansi rumah tangga. Semakin banyaknya income yang diperoleh semakin menyepelekan kita dalam mengelolanya karena lebih cenderung mengelola pengeluaran. Sementara itu Pahl (2000) menjelaskan bahwa pasangan miskin yang memperoleh pendapatan lebih rendah harus memantau situasi keuangan mereka lebih banyak daripada pasangan yang kaya. Semakin sedikit uang yang ada, semakin kuat nilainya dan semakin sulit dan menuntut pekerjaan pencatatan akuntansi keuangan keluarga.Berdasarkan uraian diatas, memberikan bukti tingkat pendapatan dampak signifikanterhadap penerapan akuntansi rumah tangga. Oleh karenaitu, hipotesiskeduadapat dirumuskanbahwa:
H2:

Tingkat

pendapatanberpengaruhterhadap penerapanakuntansi rumah tangga

\section{Gender Terhadapdan Akuntansi Rumah} Tangga

Gender atau gender sebuah pengelompokan yang diberikan kepada seseorang atas ciri-ciri khas yang dimilikinya. Gender terdiri dari laki-laki dan perempuan. Dalam penelitian sebelumnya perempuan mendominasi dalam kegiatan akuntansi rumah tangga. Menurut Syifa (2011) Sebagian besar rumah tangga di Indonesia memang membagi peran pengaturan keuangan sehari-hari dimana pembelanjaan rutin menjadi tanggungjawab seorang perempuan (mengatur uang saku anak, belanja dapur, sampai dengan urusan listrik, telepon, PAM dll). Peran perempuan seperti ini dilatarbelakangi oleh pandangan umum dimana perempuan dipandang sebagai makhluk yang jauh lebih pandai dalam mengelola keuangan keluarga dibandingkan dengan kaum pria (Gozali, 2015).Berdasarkanteoridanpenelitiansebel umnyayang memberikanbukti bahwa Gendermemiliki dampakterhadap penerapan akuntansi rumah tangga.

Sehingga dapat dibuat hipotesis:

$\mathrm{H}_{3}$ :GenderberpengaruhterhadapPenera pan akuntansi rumah tangga.

\section{Tempat Tinggal dan Akuntansi RumahTangga \\ Penelitianyang \\ dilakukansebelumnya oleh Ramlugun(2016)mengungkapkan "Kami mencoba untuk membangun hubungan yang sama dengan menyatakan bahwa unit keluarga di wilayah perkotaan akan lebih}


cenderung terhadap praktik akuntansi daripada keluarga pedesaan, lebih khusus lagi, rumah tangga perkotaan akan menerapkan praktik akuntansi yang lebih maju" sepertihalnya, studi oleh Piorkowsky (2000) mengungkapkan bahwa "membuat catatan akuntansi secara reguler lebih sering terjadi pada NeueLaĖnder (keadaan baru) daripada di AlteLaÈnder (keadaan lama)". Berdasarkanteoridanpenelitiansebelumnya yang memberikanbukti bahwa tempat tinggalmempunyai dampak signifikanterhadappenerapan akuntansi rumah tangga.Olehkarena itu,hipotesiskeempat dapat dirumuskan sebagai berikut:

\section{$\mathrm{H}_{4}$ :Tempat tinggal}

berpengaruhterhadap akuntansi rumah tangga.

\section{Metode Penelitian}

\section{Objek Penelitian}

Populasidalampenelitianini adalah dosen, petugas tata usaha dan mahasiswa padaUniversitas Sultan AgungSemarang. Pemilihan populasi pada kampus Universitas Sultan AgungSemarangkarena kampus di jalan Seroja objek penelitiannya lebih komplek.Dimana didalamnya terdapat mahasiswa regular, dan mahasiswa transfer yang mayoritas sudah bekerja dan berumah tangga, serta dosen dan pengelola yang sudah profesional.

\section{Sedangkanmetodepurposive}

sampling digunakan dalam pengambilan sampel dengan kriteria sebagai berikut: 1).

Dosen, pegawai tata usaha, dan mahasiswa di Universitas Islam Sultan Agung 2). Sudah menikah 3). Memiliki pekerjaan dan penghasilan tetap.

Variabel Penelitian dan Metode Analisis
Variabel dependen(Y)yang digunakan yaitu akuntansi rumah tangga,sedangkan variabel independen adalah tingkat pendidikan (X1), tingkat pendapatan (X2), gender (X3), dan tempat tinggal (X4). Teknik pengumpulan data dilakukan dengan menyebar kuesioner atau angket yang berisi pertanyaan, yang harus dijawab oleh keluarga besar (dosen,pegawai tata usaha, dan mahasiswa) Unissula kampus Seroja yang telah berumah tangga. Kuesioner disusun dalam tipe pilihan majemuk (multiple choice) menggunakan skala Likert, dimana setiap itemnya berupa pertanyaan dengan lima pilihan jawaban, yaitu sangat setuju (SS), setuju (S), ragu-ragu (R), tidak setuju (TS), dan sangat tidak setuju (STS).

Berikut tabel untuk menjelaskan indikator yang terdapat pada setiap variabel dan teknik pengukuran variabel.

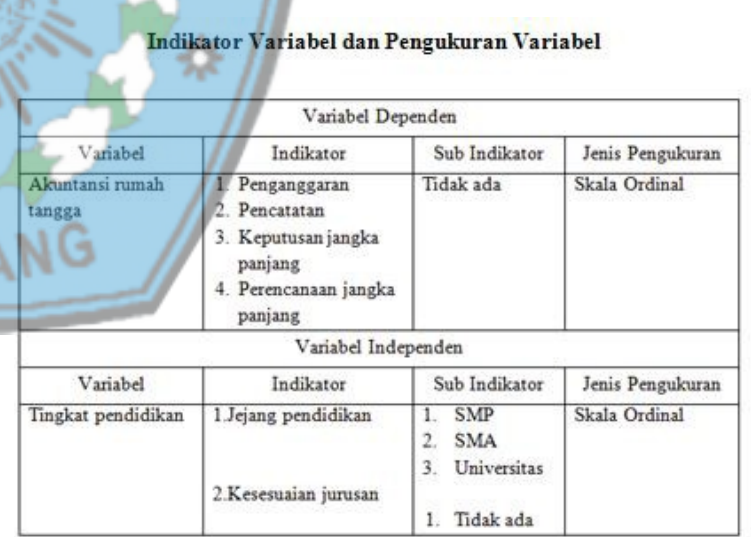

Indikator Variabel dan Pengukuran Variabel

\begin{tabular}{|l|l|l|l|}
\hline Tingkat pendapatan & $\begin{array}{l}\text { 1. Sangat tinggi } \\
\text { 2. Tinggi } \\
\text { 3. Sedang } \\
\text { 4. Rendah }\end{array}$ & Tidak ada & Skala Interval \\
\hline Gender & $\begin{array}{l}\text { 1. Laki-laki } \\
\text { 2. Perempuan }\end{array}$ & Tidak ada & Skala Ordinal \\
\hline Tempat tinggal & $\begin{array}{l}\text { 1. Urban (perkotaan) } \\
\text { 2. Rural (perdesaan) }\end{array}$ & Tidak ada & Skala Ordinal \\
\hline
\end{tabular}

Sedangkan metode analisis yang digunakan untuk menjawab hipotesis 
adalah regresi linier berganda.

$\mathrm{Y}=\mathrm{a}+\beta_{1} \cdot \mathrm{X}_{1}+\beta_{2} \cdot \mathrm{X}_{2}+\beta_{3} \cdot \mathrm{X}_{3}+\beta_{4} \cdot \mathrm{X}_{4}+\mathrm{e} \ldots . .(03)$

dimana:

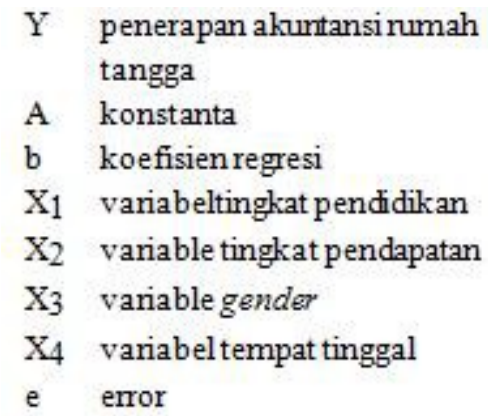

\section{Hasil dan Pembahasan}

\section{Uji Hipotesis}

Sebelum melakukan uji hipotesis, terlebih dahulu dilakukan uji validitas, reliabilitas dan uji asumsi klasik. Hasil dari uji tersebut, model penelitian menunjukan hasil yang valid, reliabel dan lolos uji asumsi klasik, sehingga memperoleh hasil uji regresi linier berganda sebagai berikut:

HasilUji RegresiLinearBerganda

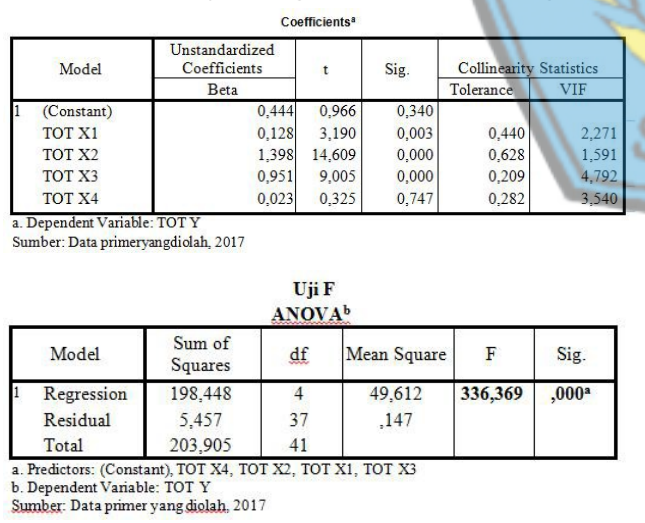

Dari hasil perhitungan dengan statistic manual diperoleh $F_{\text {hitung }} 336,369$ dengan nilai signifikasi $F$ sebesara 0,000 . Dengan menggunakan taraf signifikansi $5 \%$ maka nilai $\mathrm{F}_{\text {tabel }}$ dengan $\mathrm{df}_{1}=\mathrm{k}=4$ dan $\mathrm{df}_{2}=\mathrm{n}-\mathrm{k}-1=42-4-1=37$ diperoleh $F_{\text {tabel }}$ sebesar 2,626, maka $F_{\text {hitung }}(336,369)$ lebih besar dari $F_{\text {tabel }}(2,626)$ jadi menolak
Ho.Tingkat signifikansi $\mathrm{F}$ sebesar 0,000 lebih kecil dari 0,05 maka Ho ditolak. Dengan demikian dapat di simpulkan variabel tingkat pendidikan, tingkat pendapatan, gender,dan tempat tinggal secara bersama-sama (simultan) memiliki pengaruh yang signifikan terhadap akuntansi rumah tangga.

\section{PengaruhTingkat \\ PendidikanTerhadapAkuntansi Rumah Tangga}

Penelitianinimendapatkan hasil bahwa tingkat pendidikan memiliki pengaruhyang signifikanterhadap akuntansi rumah

tangga.Artinyaseseorangdengantingkat pendidikanyang lebihbaik, memilikipengaruh dalam penerapan akuntansirumah tanggayanglebih baik dalam

keluarganya.Hasilpenelitianinisejalandeng anpendapat dari peneliat milik Trianani

(2016)bahwa

pengetahuan

akuntansidalam

rumah

tanggasangatdiperlukan dalam

pengambilankeputusan yang

berhubungan dengankeuangan yang terjadi dalamkehidupan sehari-hari, sehinggamampu untuk merencanakan keuangan dengan tepat dan terbebasdari masalah keuangan.

Dalampenelitian inipendidikan yang diterimaakanmenjadikanseseorang menjadi lebih bijak dan lebih baikdalam bersikap untuk keuang rumah tangga mereka agar terhindar dari kekeliruanyang dapat memicu pertengkaran dalam rumah tangga.Berbeda dengan penelitian milikRamlugun(2016) menyatakan bahwa tidak ada hubungan yang signifikan antara tingkat pendidikan dan akuntansi rumah tangga. Salah satu penjelasan adalah 
akuntansi sangat terkait dengan kehidupan pribadi sejauh menyangkut bisnis ini, terlepas dari tingkat pendidikan yang telah dicapai.

\section{PengaruhTingkat}

\section{PendapatanTerhadapAkuntansi Rumah Tangga}

Penelitianinimendapatkan hasil bahwa tingkat pendapatan memilikipengaruhyangsignifikanterhadap akuntansi rumah tangga.Tingkat pendapatan dapat meningkatkan pengaruhdalam penerapan akuntansi rumah

tangga,sehinggaseseorangdapatmenghasil kankualitas keuangan rumah tangga yang menerapakan konsep akuntansi rumah tanggayanglebih baik.Hasil ini sejalandengan penelitian milikRamlugun (2016) bahwa ada hubungan antara akuntansi rumah tangga dan tingkat pendapatan.

Nurhayati

(2016)dengan menerapkan akuntansi rumah tangga di keluarga, mereka dapat menilai pendapatan yang diperoleh.Hal ini penting karena berkaitan dengan penilaian pajak penghasilan yang memerlukan dokumen pendukung untuk membuktikan dan menentukan potongan pajak yang di bebankan.Penelitian kondisi keuangan keluarga dapat dikatakan surplus jika pendapatannya lebih besar dibanding dengan pengeluarannya, baik dalam harian, mingguan, bulanan, atau tahunan (Wiyono, 2014:4).

\section{PengaruhGenderTerhadap Akuntansi Rumah Tangga.}

Penelitianinimendapatkan

kesimpulan

bahwagender

memilikipengaruhyang signifikan terhadap tingkat kualitas rumah tanggadengan arah koefisienpositif. Artinya dalam hal ini gender khususnya perempuanberpengaruh positif dalammemberikan kualitas akuntansi rumah tangga yang lebih baik bagi keluarganya.Hasilinitidak sejalan dengan penelitian milik Ramlugun (2016) dalam penelitiannya gender memberikan hasil yang beragam, tidak ada perbedaan seperti yang ditemukan di Mauritius. Hal ini dapat dijelaskan dengan kesetaraan gender di Mauritius. Selain itu, hal ini juga dapat dijelaskan oleh pemberdayaan perempuan dan peningkatan kendali perempuan.Syifa (2011)mengungkapkan bila perempuan memegang kendali dalam manajemen keuangan keluarganya, maka keuangan keluarga tersebut bisa menjadi lebih maksimal.

\section{Pengaruh Tempat TinggalTerhadap}

Akuntansi Rumah Tangga. Penelitian inimendapatkan hasil bahwatempat tinggal memilikipengaruhyangpositif yang tidak signifikanterhadap akuntansi rumah tangga.Kondisi

demikianmenunjukkanbahwahipotesis ke empat ditolak dalam penelitian ini.Artinya tempat tinggaltidak dapatmeningkatkanpengaruh penerapan akuntansi rumah tangga.Sejalan denganRamlugun (2016)sejauh menyangkut lokasi geografis, hasil dapat dijelaskan oleh fakta bahwa ada perbedaan yang tidak signifikan antara daerah perkotaan dan pedesaan.Perbedaan wilayah dan tempat tidak dapat mempengaruhi penerapan 
akuntansinya.Hal ini bisa disebabkan tidak adanya hubungan yang kuat atas individu yang menerapkan akuntansi rumahtangga terhadap tepat tinggal atau lokasi individu itu berada. Diera sekarang yang semakin maju, hampir tidak ada perbedaan antara dikota dan di desa karena akses informasi yang semakin transparan.

\section{Kesimpulan, Keterbatasan dan Saran}

Berdasarkan analisis statistik yang telah dilakukan menunjukkan bahwatingkat pendidikanterhadap akuntansi rumahtanggamemiliki pengaruhyang signifikan.Kondisidemikian terjadi bilamana seseorangdengantingkat pendidikanmenengah $\geq$ keatas, memilikipengaruh dalam penerapan akuntansirumahtanggayanglebih ( baik dalam keluarganya.Tingkat pendapatanterhadapakuntansi rumahtangga memilikipengaruhyangsignifikan.

Sejalandengan penelitian milikVidisha G.R (2016) bahwa ada hubungan antara akuntansi rumahtangga dan tingkat pendapatan. Statistik Chi-square menunjukkan bahwa hipotesis tersebut didukung pada tingkat signifikansi 10\% yaitu praktik akuntansi rumah tangga yang memang dipengaruhi oleh pendapatan.Genderberpengaruh signifikan terhadap akuntansi rumah tangga hal ini terlihat dari jawaban responden dimana $62 \%$ responden menyatakan setuju wanita lebih baik dibanding pria. Sedangkan Tempat tinggal terhadap akuntansi rumahtanggatidak memiliki pengaruh atau tidak signifikan,hasil ini terjadi dikarenakan adanya fakta bahwa tidak ada perbedaan pengelolaan yang signifikan antara daerah perkotaan dan pedesaan.

Keterbatasan dalam penelitian ini terletak pada populasi penelitian.Populasi penelitian hanya di Universitas Islam Sultan Agung Semarang, sehingga objeknya kurang luas.Bagi penelitian selanjutnya, diharapkan untuk memperbanyak sampel penelitian, menambah jangka waktu penelitian, dan menambah variabel-variabel independen lainnyaagar dapat memperoleh hasil yang optimal misalnya beban tanggungan keluarga, beban hutang, pajak penghasilan.

\section{Daftar Pustaka}

Asri, Komang Pratiwi. I.B.Putra Astika dan I.D.G. Dharma Suputra. 2007. Pengaruh Independensi dan Kompetensi Auditor pada Kualitas Audit dengan Due Professional Care sebagai Variabel Intervening di KAP se-Provinsi Bali.Universitas Udayana Bali.

Chotimah, Chusnul dan Suci. R. 2013. Pengaruh Pendidikan Keuangan di Keluarga, Sosial Ekonomi Orang tua, Pengetahuan Keuangan, Kecerdasan Spiritua, dan Teman sebaya Terhadap Manajemen Keuangan Pribadi Maha siswa S1 Pendididkan Akuntansi Fakultas Ekonomi Universitas Negeri Surabaya.

Chowa, G. A. N. 2006. Savings performance among rural households in Sub - SaharanAfrica: The effect of Gender. Joernal Social Development Issues, 28(2), 106 - 116. 
Ghozali, Imam \& Anis Chariri. 2014. Teori Akuntansi, Edisi 3, Semarang: BP Universitas Diponegoro.

Ghozali, Imam, 2013. Aplikasi Analisis Multivariate Dengan Program IBM SPSS 21. Semarang: Badan Penerbit Universitas Diponegoro.

Gozali,Ahmad. 2015. Habiskan Saja

Gajimu. Jakarta: Trans Media.

Harjanto, Atta Putra. 2014. Pengaruh

Kompetensi, Independen, Objektivitas,

Akuntabilitas dan Integritas Terhadap

Kualitas Audit dengan Etika Auditor

Sebagai Variabel Moderasi.

Universitas Diponegoro

Ihsan, Fuad. 2010. Dasar-dasar

kependidikan. Jakarta: PT. Rineka Cipta.

Istrilista, Trifena Maria, 2016. Pengaruh

Pendapatan dan Pengetahuan

Keuangan Terhadap Perencanaan

Keuangan Keluarga di Surabaya.

Luhung, Husny Rabista H. R.

2016.Pengaruh Pendapatan Orangtua terhadap Alokasi Pendidikan anak pada Pengrajin Tikar dengan Orientasi Orangtua sebagai Variabel Intervening. Manurung, Daniel T. H dan Jimmi Sinton. 2013. Urgensi Peran Akuntansi dalam Rumah Tangga.

Mulyani, Sri. 2015. Peran Gusjigang dan Penerapan Akuntansi Terhadap Literasi Keuangan Pra-Nikah.

Notoatmodjo, Soekidjo, 2010. Pendidikan dan Perilaku Kesehatan.Jakarta : Rineka Cipta.

Nurhayati \& Noor Hasniza Haran, 2016. Akuntansi Rumah Tangga: Jalan Menuju Ketahanan Ekonomi.

Pahl, J. 2000. Couples and their money: patterns of accounting and accountability in the domestic economy. Accounting, Auditing \& Accountability Journal,Vol 13 (4), $502-517$

Purwidianti, Wida dan Rima Mudjiyanti.2016.Analisis Pengaruh Penglaman Keuangan dan Tingkat Pendapatan Terhadap Prlaku Keuangan Keluarga di Kecamatan Purwokerto Timur. Jurnal Menejemen dan Bisnis, Vol 1(2) 141-148

Piorkowsky, M. B. 2000. Household Accounting in Germany, Some statisticalevidence and the development of new systems.Accounting, Auditing \&Accountability Journal, Vol 13(4), $518-534$.

Rani, P.A.A. 2014. Kemampuan Asimetri Informasi, Ketidakpastian Lingkungan, Budget Emphasis, dan Kepastian Individu Sebagai Variabel Moderasi Terhadap Partisipasi Anggaran Pada Budgetary Slack (studikasus SKPD di Kabupaten Bandung, Bali).

Rumlugun,V. G. 2016. An Evaluation of Household Accounting inMauritius, macrothik Institute.

Setiowati, Nur Eka.2016. Perempuan, Strategi Nafkah dan Akuntansi Rumah tangga.

Silalahi, Harini Triana . 2016. Studi Komparasi Tingkat literasi Keuangan Keluarga di desa Condongcatur Yogyakarta Ditinjau dari Status Sosial Ekonomi dan Gaya Hidup,.

Syifa, L. L, 2011. Peran Perempuan dalam Manajemen Keuangan Keluarga Muda. Wiyono. M. M., 2014. Perencanaa Keuangan Keluarga di Malang. Direktorat Penelitian dan Pengabdian Universitas Muhamadiyah Malang. 